DOI: 10.31866/2617-2674.3.2.2020.217637

УДК 070.16:654.19:7.097

\title{
НОВИННИЙ КОНТЕНТ
}

У СУЧАСНОМУ ПРЯМОЕТЕРНОМУ МОВЛЕННІ

\author{
Ірина Гавран ${ }^{1 a}$, Марина Дубина $^{2 a}$ \\ ${ }^{1}$ кандидат педагогічних наук, доцент; \\ e-mail: yarynka.77@gmail.com; ORCID: 0000-0002-6777-3038 \\ ${ }^{2}$ магістрант кафедри тележурналістики та майстерності актора; \\ e-mail: marysol_08@ukr.net; ORCID: 0000-0003-3159-5337 \\ а Київський національний університет культури і мистецтв, Київ, Україна
}

\section{Ключові слова:}

прямоетерне мовлення; пряма трансляція;

новинний відеоконтент; телеканали; тележурналіст

\begin{abstract}
Анотація
Мета дослідження - дослідити новинний контент у сучасному прямоетерному мовленні. Методологія дослідження базується на використанні загальнонаукових методів: аналізу (послідовного викладу теоретичного та практичного матеріалу, що використовувався В дослідженні); синтезу (викладу логічного висновку); емпіричних (спостереження, прогнозування, дослідження та порівняння); методу систематизації та узагальнення матеріалу. Наукова новизна одержаних результатів полягає у розкритті змісту концепції прямих трансляцій, дослідження яких мало розкриті у сучасному науковому медійному світі, та вперше переформовані уявлення про роботу тележурналіста під час прямого етеру на українських телеканалах. Висновки. У ході дослідження було розкрито стрижневі аспекти новинного контенту у сучасному прямоетерному мовлені. Проаналізовано наукові та інтернет-джерела, в яких є інформація, пов'язана з мовною деструкцією, що розкриває загальні розуміння тележурналістами структури щодо подачі інформації під час прямої трансляції.
\end{abstract}

\section{Як цитувати:}

Гавран, І. та Дубина, М. (2020). Новинний контент у сучасному прямоетерному мовленні. Вісник Київського національного університету культури і мистецтв. Серія: Аудіовізуальне мистецтво і виробництво, 3(2), с.175-181.

\section{Постановка проблеми}

Прямі трансляції в сучасному медійному просторі відіграють ключове місце і продовжують його тримати. Все більше глядача цікавить саме контент з місця подій. Їм хочеться відчувати себе там, не дивлячись, що вони сидять біля екрана телевізора або смартфона.

Питання новинного контенту в сучасному медійному просторі повністю й досі не розкрито. Ця тема продовжує бути актуальною і для подальшого дослідження, адже щодня прямі етери 
Вісник Київського національного університету культури і мистецтв

Серія: Аудіовізуальне мистецтво і виробництво

стають ще цікавішими, унікальними та актуальними, особливо з наукової точки зору.

\section{Аналіз останніх досліджень і публікацій}

Слід зазначити, що тема прямих трансляцій недостатньо висвітлена, але варто звернути увагу на дослідження О. Ятчук, яка розкриває жанрові особливості прямоетерного мовлення; А. Капелюшного, що дослідив мовну компетентність тележурналістів під час прямого етеру; І. Абрамової, яка дослідила проблематику та функціонування прямоетерного мовлення.

\section{Мета дослідження}

Мета дослідження - проаналізувати новинний контент у сучасному прямоетерному мовленні.

\section{Виклад основного матеріалу}

Велика роль в новинах на телебаченні належить прямому репортажу. Він має найбільшу силу впливу на аудиторію, адже має можливість побачити або почути подію під час її розвитку. Прямоефірне мовлення ототожнене з інтерактивним. Хоча на телебаченні їх досі вважають різними проєктами.

Доцільно зазначити, що прямі трансляції - це найоперативніше, що існує зараз не тільки на сучасному телебаченні, а й в Інтернеті. Щодня все більше людей ведуть прямі етери та пробують себе в ролі телеведучих, тим самим набирають перегляди, лайки та підписки. Навіть українські телеканали останні роки розкручують себе в соціальних мережах та проводять прямі етери окремо від того, що показують по телевізору, адже подивитися збережене відео або прокрутити його - приваблює сучасних глядачів більше (Абрамова, 2013).

Прямі трансляції, які демонструють на телебаченні, не завжди потрапляють в мережу, тому вони частіше залишаються непримітними. В мережі ж навпаки, кореспонденти розуміють, що вся їх робота побудована на прямому етері та це все залишиться на сторінці, яку кожен може переглянути. Або, як ще зараз популярно, цей етер з'явиться на YouTube і буде доступний всьому світові.

Більшість тележурналістів під час своїх трансляцій на телебаченні майже завжди виглядають розгублено і не знають, що ж сказати, а що ні. Їхня робота саме в цю секунду полягає в тому, аби максимально чітко та правдиво донести інформацію з місця подій. Знаходячись на місці події, вони мають точно та неупереджено володіти інформацією і говорити лише перевірені та відомі факти.

Розгубленість під час прямих трансляцій $є$ найбільшою проблемою. Частіше за все вона виникає через недосконале знання української мови або через відсутність професійних навичок. Аналізуючи рівень сучасної мови, можна зазначити, що через ії не знання у більшості тележурналістів і виникають ситуації, через які вони ніяковіють. "Аааа», «Шо», «Ну», «Ага» тощо... Ці словапаразити дуже часто можна почути під час трансляцій як на телебаченні, так і в Інтернеті. Відбувається це через те, що мова більшості заспамлена словамипаразитами, якими користуються в житті. Але під час етеру це виглядає недоречно та непрофесійно. Тому треба працювати над тим, щоб викорінювати їх зі свого буденного життя. Допомагають спеціальні тренінги, курси та постійна 
Bulletin of Kyiv National University of Culture and Arts

Series in Audiovisual Arts and Production

робота над собою перед дзеркалом. Загалом помилки у тележурналістів виникають під час наголошування слів. Це пояснюється впливом діалектних особливостей, а також великою кількістю русизмів в мові (Капелюшний, 2011b).

Так, А. Капелюшний (2011a) в своїй науковій статті «Мовна компетентність телевізійних журналістів у прямоефірних виступах» вказує на те, що "рівень загальної, а не лише мовної компетентності журналістів найефективніше, найшвидше виявляють такі інтегровані мовні індикатори, як уживання іншомовних слів і особливо правильність/ неправильність наголошування слів. Причому спрацьовує цей індикатор здебільшого тоді, коли виникають помилки в прямоефірному мовленні телевізійних журналістів».

В етерах на телеканалах інколи працюють люди без спеціалізованої телевізійної освіти. Через незнання теоретичного матеріалу та певних законів, іноді починаються проблеми, які може помітити навіть звичайний глядач.

Тележурналісти, які працюють в прямому етері в Інтернеті - стрімі - не мають права на помилку. Здебільшого, це кореспонденти, які працюють в інформаційних агентствах. Як мінімум тому, що провідні медіа черпають інформацію саме звідти, переслуховують і ретельно перевіряють (принаймні, так має бути). Варто звернути увагу на важливість зосередження на всіх етапах прямої трансляції, адже помилка може загрожувати величезними штрафами або навіть судовими тяганинами. Тележурналіст повинен бути впевненим в кожному слові, звуці та навіть повороті своєї голови. Адже проаналізувати повтор в мережі набагато простіше. Тут важливий погляд, посмішка (якщо до- речна) та жести, які відіграють значну роль. Тележурналіст має стежити, аби все, про що він говорить, було структуровано та без інформаційних перекручень. Оперування фактами допоможе уникнути проблемних ситуацій.

Слід зазначити, що той, хто працює наживо потенційно має бути готовим до усього. Наприклад, вчасно не увімкнеться техніка, ситуація зміниться за секунду до виходу в етер або тележурналіст забуде, структуровану в голові, інформацію, про яку повідомлятиме в етері. Проблеми з апаратурою виникають часто, тому потрібно бути готовим увімкнутися на телефон та зробити трансляцію в записі.

Крім звичайних прямих трансляцій глядачів цікавлять і прямоефірні проєкти. Для того, аби такий проєкт вийшов до етеру, тележурналіст проводить величезну підготовчу роботу. Він обирає тему, збирає аудіовізуальну та текстову інформацію, пише план та з точністю розраховує для нього час, працює над сценарним планом, готує додаткові питання (у випадку, коли основні вичерпаються), а також перед етером знайомиться та спілкується з гостем, щоб налагодити контакт (Абрамова, 2013).

Одним з найпопулярніших жанрів прямого етеру є інтерв'ю. Його особливістю $€$ непідробні емоції та неповторність. Такий прямий етер неможливо прорепетирувати, тут важливі: міміка, жести та імпровізація. Остання, до речі, може бути головним компонентом всю програму (Прямий ефір як діалогічна форма телевізійного мовлення, 2014). У своєму дослідженні «Публицист и действительность» Е. Прохоров (1973, с.46) зазначав, що перегляд тележурналістом кожного свого етеру або трансляції та аналіз виконаної роботи удосконалюють робочі 
Вісник Київського національного університету культури і мистецтв.

Серія: Аудіовізуальне мистецтво і виробництво

навички, та запобігають виникненню помилок в майбутньому.

Зовнішній вигляд тележурналіста в етері є однією із фундаментальних складових сприйняття реципієнтами донесеної інформації. Якщо він втомлений та розгублений - глядач одразу це побачить, і навіть грим та зачіска можуть не врятувати ситуацію: відсутність зосередженості глядача на інформації позбавляє можливості сприймати іï правильно. В новинах ведучі завжди виглядають так, немов вони з обкладинки журналу, а от тележурналісти, які підключаються до етеру, мають не завжди презентаційний вигляд. Тому важливо в цю секунду залишатися не лише професіоналом, а й обличчям каналу.

Слід сказати, що під час трансляцій багато чого ще залежить від редакторів, з якими тележурналісти постійно на зв'язку та передають потрібну інформацію для ведучого новин, який знаходиться в етері. Саме редакційна робота - спрямувати та вчасно подати потрібний сигнал тележурналісту, який в центрі події - дає результат, що або зацікавить, або пройде повз глядача. Буває так, що один тележурналіст працює під будівлею суду, а інший - в залі судового засідання. До етеру виходить тележурналіст, який працює зовні. Отже, основна інформація із зали суду надходить йому в телефонному режимі, і її варто розділити за лічені хвилини на ту, яка увійде до підводки ведучого та трансляції. Не менш важливо її швидко структурувати, запам'ятати (читання з телефону виглядає жахливо) та донести глядачу.

Дослідниця О. Ятчук (2019) у своїй праці «Прямоефірне та інтерактивне мовлення: жанрові особливості» наголошувала: «Випуск новин, як програма що належить до інформаційних жанрів, використовує прямий ефір як основний спосіб організації інформації (з використанням «прямих включень»). Також до інформаційних жанрів належать трансляції урочистих подій (змагань). Проте використання інтерактивності у цьому виді мовлення носить опосередкований характер і налаштований більше на подальшу комунікацію з використанням окремих touch points».

На новинних каналах все частіше проводять стріми. Саме під час їх трансляції глядач в реальному часі бачить те, що відбувається на конкретній події або ситуації, та може ставити свої запитання у коментарях. Стрім - це зовсім новий формат подачі матеріалу, який подається у відео або аудіо. Стрімери в Інтернеті набирають мільйони переглядів, адже вони показують та коментують, наприклад, як в прямому етері грають в ігри, підіймаються на різні споруди або показують надзвичайні ситуації, які відбуваються тут і зараз. На стрімах присутнє живе спілкування між коментатором та глядачами. Іноді так відбувається, що під час стрімтрансляції ведучий може прислуховуватися до тих, хто його дивиться. Якщо поради йому допоможуть в ситуації, то він навіть може якось нагородити глядача. Доцільно сказати, що в Україні все частіше за допомогою стріму проводять різноманітні майстер-класи, вебінари та навчальні курси (Что такое Стрим? (Stream), 2019).

Згідно з нашим дослідженням з'ясовано, що карантин 2020 року вплинув на те, що майже 95 \% українців почали використовувати Інтернет не лише для розваг, але й для роботи. Тому прямі трансляції, стріми та етери набрали більшої популярності. Періодичність їх 
публікацій збільшилася, а левова частка глядачів тепер прямо з дому змогла стати частиною цього дійства. На своїх сторінках в соціальних мережах люди в прямому етері спілкуються так, як їм зручно. Подібний формат не викликає подиву, зайвої уваги і критики з боку реципієнтів етеру. В новинах же або в розважальних програмах (не розмежовуючи телебачення та Інтернет) така манера спілкування суперечить світовим медійним стандартам. Глядач хоче бачити ідеальну картинку, правильну мову, жодних заїкань та непідробні емоції.

\section{Висновки}

Працюючи у прямих етерах, можна дійти висновку, що це неабиякий саморозвиток, який триває 24 години щодня. Адже готуючись до виходу в етер, потрібно переглянути велику кількість достовірних джерел, поспілкуватися з компетентними людьми, аби у прямій трансляції донести інформацію без перекручень. Шансу на другу спробу у тележурналіста немає.

Кожен, хто працює наживо повинен мати натреновану пам'ять. Адже тележурналісту завжди потрібно тримати безліч інформації в голові, структурувати та подавати згідно з хронологією.

Професійний тележурналіст, який хоче працювати наживо має бути готовий до всього: відвідувати «гарячі» точки, залишатися чергувати всю ніч, ночувати в машині, на базі, в полі, прокидатися рано навіть після пізнього етеру тощо. Отже, робота тележурналіста - це, перш за все, виховати в собі високий рівень стресостійкості та можливість бути першим, хто презентує унікальну інформацію в етері.

\section{СПИСОК ПОСИЛАНЬ}

Абрамова, І.Г. та Заводовська, О.А., 2013. Прямоефірна програма: сутність, проблематика створення та функціонування. Держава та регіони. Соціальні комунікації, [online] 1, с.3843. Доступно: <http://irbis-nbuv.gov.ua/cgi-bin/irbis_nbuv/cgiirbis_64.exe?C21COM=2\&I21DBN =UJRN\&P21DBN=UJRN\&IMAGE_FILE_DOWNLOAD=1\&Image_file_name=PDF/drsk_2013_1_10. pdf> [Дата звернення 28 квітня 2020].

Капелюшний, А., 2011а. Мовна компетентність телевізійних журналістів у прямоефірних виступах. Вісник львівського університету. Серія Журналістика, [online], 34, с.226-230. Доступно: <old.journ.Inu.edu.ua/publications/visnyk34/Visnyk\%2034_P2_02_Kapeliushny.pdf> [Дата звернення 29 квітня 2020].

Капелюшний, А., 2011b. Телебачення прямого ефіру: практика мовлення, типові помилки. Львів: ПАІС.

Прохоров, Е.П., 1973. Публицист и действительность. Москва: МГУ.

Прямий ефір як діалогічна форма телевізійного мовлення, 2014. Студалл.Орг. [online] Доступно: <https://studall.org/all2-5433.html> [Дата звернення 30 квітня 2020].

Что такое Стрим? (Stream), 2019. [online] Доступно: <http://chto-takoe.net/chto-takoe-strimstream/> [Дата звернення 30 квітня 2020].

Ятчук, О., 2019. Прямоефірне та інтерактивне мовлення: жанрові особливості. Образ [online], 3, с.126-135. Доступно: <https://essuir.sumdu.edu.ua/handle/123456789/77195> [Дата звернення 29 квітня 2020]. 


\title{
REFERENCES
}

Abramova, I.H. and Zavodovska, O.A., 2013. Priamoefirna prohrama: sutnist, problematyka stvorennia ta funktsionuvannia [Live program: essence, problems of creation and functioning]. Derzhava ta rehiony. Sotsialni komunikatsii, [online] 1, pp.38-43. Available at: <http://irbis-nbuv. gov.ua/cgi-bin/irbis_nbuv/cgiirbis_64.exe?C21COM=2\&I21DBN=UJRN\&P21DBN=UJRN\&IM AGE_FILE_DOWNLOAD=1\&Image_file_name=PDF/drsk_2013_1_10.pdf> [Accessed 28 April 2020].

Chto takoe Strim? (Strim) [What is Stream? (Strim)], 2019. [online] Available at: <http://chtotakoe.net/chto-takoe-strim-stream/> [Accessed 30 April 2020].

latchuk, O., 2019. Priamoefirne ta interaktyvne movlennia: zhanrovi osoblyvosti [Live and interactive speech: genre features. Image]. Obraz [online], 3, pp.126-135. Available at: <https:// essuir.sumdu.edu.ua/handle/123456789/77195> [Accessed 29 April 2020].

Kapeliushnyi, A., 2011a. Movna kompetentnist televiziinykh zhurnalistiv u priamoefirnykh vystupakh [Language competence of television journalists in live broadcasts]. Visnyk Ivivskoho universytetu. Seriia Zhurnalistyka, [online], 34, pp.226-230. Available at: <old.journ.Inu.edu.ua/ publications/visnyk34/Visnyk\%2034_P2_02_Kapeliushny.pdf> [Accessed 29 April 2020].

Kapeliushnyi, A., 2011b. Telebachennia priamoho efiru: praktyka movlennia, typovi pomylky [Live television: speech practice, common mistakes]. Lviv: PAIS.

Priamyi efir yak dialohichna forma televiziinoho movlennia [Live broadcast as a dialogic form of television broadcasting], 2014. Studall.Orh. [online] Available at: <https://studall.org/all2-5433. html> [Accessed 30 April 2020].

Prohorov, E.P., 1973. Publicist i deǏstvitel'nost' [Publicist and reality]. Moscow: MGU.

\section{НОВОСТНОЙ КОНТЕНТ В СОВРЕМЕННОМ ПРЯМОЭФИРНОМ ВЕЩАНИИ}

\section{Ирина Гавран ${ }^{1 a}$, Марина Дубина $2 \mathrm{a}$}

\author{
${ }^{1}$ кандидат педагогических наук, доцент; \\ e-mail: yarynka.77@gmail.com; ORCID: 0000-0002-6777-3038 \\ ${ }_{2}^{2}$ магистрант кафедры тележурналистики и мастерства актера; \\ e-mail: marysol_08@ukr.net; ORCID: 0000-0003-3159-5337 \\ ${ }^{a}$ Киевский национальный университет культуры и искусств, Киев, Украина
}

\begin{abstract}
Аннотация
Цель исследования - исследовать новостной контент в современном прямоэфирном вещании. Методология исследования базируется на использовании общенаучных методов: анализа (последовательного изложения теоретического и практического материала, который использовался в исследовании); синтеза (изложения логического вывода); эмпирических (наблюдения, прогнозирования, исследования и сравнения); метода систематизации и обобщения материала. Научная новизна исследования заключается в раскрытии содержания концепции прямых включений, исследование которых мало раскрыты в современном научном медийном
\end{abstract}


мире, и впервые переформированы представления о работе тележурналиста во время прямого эфира на украинских телеканалах. Выводы. В ходе исследования были раскрыты стержневые аспекты новостного контента в современном прямоэфирном вещании. Проанализированы научные и интернет-источники, в которых есть информация, связанная с речевой деструкцией, которая раскрывает общие понимания тележурналистами структуры относительно подачи информации во время прямых включений.

Ключевые слова: прямоэфирное вещание; прямые включения; новостной видеоконтент; телеканалы; тележурналист

\title{
NEWS CONTENT IN MODERN LIVE BROADCASTING
}

\author{
Iryna Gavranª, Maryna Dubyna2a \\ ${ }^{1}$ PhD in Pedagogy, Associate Professor; \\ e-mail: yarynka.77@gmail.com; ORCID:0000-0002-6777-3038 \\ 2 Master's Degree Student, Television Journalism and Actor's Skills Department; \\ e-mail: marysol_08@ukr.net; ORCID: 0000-0003-3159-5337 \\ ${ }^{a}$ Kyiv National University of Culture and Arts, Kyiv, Ukraine
}

\begin{abstract}
The purpose of this research is to research news content in modern live broadcasting. The research methodology is based on the use of general scientific methods: analysis (consistent presentation of theoretical and practical material used in the study); synthesis (presentation of the logical conclusion); empirical (observation, forecasting, research and comparison); method of systematization and generalization of material. The scientific novelty of the obtained results lies in the content disclosure of the direct inclusions' concept, the research of which was disclosed little in the modern scientific media world, and ideas about the TV journalist work during the live broadcast on Ukrainian TV channels was reformed for the first time. Conclusions. During the study, the core aspects of news content in modern live broadcasting were discovered. Scientific and Internet sources are analyzed, in which there is information related to speech destruction, which reveals the general understanding of TV journalists of the structure regarding the information's submission during the live broadcasts.
\end{abstract}

Keywords: live broadcasting; direct inclusion; news video content; TV channel; TV journalist 